\title{
Design Of Geographic Learning Development Research City Oriented City in FIS Unima Geography Department
}

\section{Desain Perangkat Pembelajaran Geografi Desa Kota Berorientasi Riset Di Jurusan Geografi FIS Unima}

\author{
Robot Jelly* \\ Universitas Negeri Manado
}

Received: 25 September Revised: 30 September Accepted: 7 Oktober

\begin{abstract}
Abs tract
This research is a research development that aims to: 1) produce a prototype product of a validated researchoriented urban village geography learning tool, 2) a research-oriented urban village geography learning tool guide product in higher education especially in the FIS UNIMA geography education department. The sample in this study is the fifth semester students of geography department. the research process is the analysis of the material, the preparation of learning device designs, making prototypes of activity guides and learning processes, testing the prototypes, repairing / revising according to the evaluation results. To obtain the feasibility of a research-oriented urban village geography learning tool, a trial and evaluation of the product is carried out through three stages, namely 1) validation of the material expert and expert. 2) field trials, 3) product analysis and revision. The results of the study show that 1) A validated study guide for the study activities of the geography of the urban village. 2) The results of product trials in the field through on-line learning object tracking and the surrounding environment. 3) produce an example of scientific work by selecting Cihedeung village in Bandung regency. Thus all the learning steps in the design of researchbased urban village geography learning tools meet validity criteria so that it can be used in geography learning of urban villages in the geography department of FIS Unima
\end{abstract}

Keywords: Design, Learning Tools, Research Based. 


\section{PENDAHULUAN}

Dalam rangka implementasi kurikulum perguruan tinggi berbasis KKNI , program studi pendidikan geografi FIS UNIMA mempunyai tugas utama mengimplementasikan kurikulum perguruan tinggi berbasis KKNI dengan mendesain model dan perangkat pembelajaran di jurusan Geografi prodi pendidikan Geografi. dalam memenuhi standar Nasional Pendidikan, dan penelitian dan Pengabdian kepada Masyarakat, dalam mempersiapkan sumberdaya manusia yang berkualitas dan mampu bersaing. Untuk mencapai tujuan tersebut maka FIS UNIMA harus selalu meningkatkan kualitasnya melahui berbagai kegiatan terutama melalui peningkatan standar nasional pendidikan khususnya standar proses pembelajaran/perkuliahan, standar penelitian, karena selama ini kualitas pendidikan di FIS UNIMA lebih khusus program studi pendidikan geografi menunjukan tingkat pencapaian ranah kognitif yang masih rendah yaitu masih sebatas pada ranah pengetahuan, pemahaman dan aplikasi sedangkan untuk tingkat berpikir yang tinggi belum tercapai apalagi pencapaian psikomotorik dalam berbagai kompetensi dasar geografi masih jauh dari yang diharapkan. Hal ini terbukti dalam setiap ujian komprehensif begitu banyak calon lulusan yang menulis skipsi diluar kajian geografi atau bersifat tulisan umum. Yang lebih memprihatinkan lagi yaitu ditemukan sejumlah skripsi yang diduga plagiarisme.

RPS (Rencana Pembelajaran Semester) dan Rencana Pelaksanaan Pembelajaran semester yang rumit menyebabkan banyak dosen tidak memperbaharui RPS di setiap semester. Pada hal bagian ini tugas dari dosen ialah merancang kegiatan pembelajaran yang mengikuti dinamika perkembangan waktu. Disisi lain tuntutan akan kompetensi lulusan yang relevan dengan kebutuhan kompetensi lulusan yang relevan dengan kebutuhan dunia kerja wajib untuk dipenuhi. Untuk itu perlu dikembangkan model desain RPS yang berorientasi riset sebagai perancangan RPS yang adaptif dengan peraturan kebijakan pendidikan tinggi seperti berbagi dokumen konten yang terintegrasi dan fitur yang mengijinkan kolaboratisi antar dosen. Pengembangan desain RPS berorientasi riset menunjang kedinamisan model pengembangan kurikulum saat ini.

Berdasarkan kebutuhan tersebut maka penulis berasumsi bahwa melalui desain perangkat pembelajaran geografi berorientasi riset di jurusan geografi FIS UNIMA akan meningkatkan kualitas kompetensi lulusan dan meminimalisir terjadinya plagiarism. Desain pembelajaran geografi desa kota berbasis riset merupakan cara berpikir mahasiswa yang luas dan konkrit karena mahasiswa diperhadapkan pada perkuliahan yang faktual sehingga mahasiswa memiliki kompetensi lulusan sebagaimana diharapkan dalam desain pembelajaran geografi desa berbasis riset.

Tujuan khusus penelitian ini adalah: 1) Mengembangkan desain perangkat pembelajaran geografi desa kota berorientasi riset dengan prosedur kegiatan yaitu menyusun rencana produk yang akan dikembangkan dan divalidasi yang meliputi analisis materi, penyusunan rancangan model, menguji prototipe, membuat prototipe panduan kegiatan dan proses belajar mengajar, perbaikan prototipe dan 
dan panduan kegiatan dan pembelajaran. 2) menyusun sistimatika panduan pembelajaran geografi berbasis masalah dan penugasan berorientasi riset. 3) Melaksanakan pembelajaran geografi desa kota sesuai RPS yang berorientasi riset dan melaksanakan uji coba dan evaluasi produk untuk memperoleh kelayakan desain perangkat pembelajaran yang sudah dirancang beserta panduannya.

Perangkat pembelajaran sebagai bagian dari kelengkapan proses pembelajaran diatur dalam Peraturan Menteri Riset dan Teknologi dan Pendidikan Tinggi (Permenristekdikti) no. 44 tahun 2015 tentang Standar Nasional Pendidikan Tinggi (SN Dikti) pasal 12, : Perencanaan proses pembelajaran disajikan dalam RPS dan disusun oleh dosen baik ada dalam RPS mencakup hal-hal sebagai berikut: 1) Identitas program studi dan penyusunan RPS, 2) Capaian pembelajaran mata kuliah (CPMK), 3) Kemampuan akhir yang diharapkan, 4) Bahan Kajian (BK), 5) Metode pembelajaran 6) Waktu yang disediakan untuk mencapai kemampuan akhir, 7) Pengalaman belajar, 8) Kreteria, indicator dan bobot penilaian 9) Referensi yang diacu. Tahapan-tahapan pengembangan RPS, mengacu pada berbagai leteratur adalah sebagai berikut: 1) Perencanaan melalui serangkaian analisis kompetensi dan rangkaian sikap, penetahuan, keterampilan umum, dan keterampilan khusus yang harus dicapai secara bertahap dan berkesinam Bungan. 2) Pelaksanaan penyusunan berpedoman pada mata kuliah tersebut 3) Perbaikan dilakukan dengan evaluasi pelaksanaan proses pembelajartan, tracer study, dan lain-lain. 4). Peningkatan kualitas RPS didasarkan pada hasil evaluasi dan masukan dari pakar. 5)Penilaiam RPS dilakukan secara berkala dengan menggunakan metode-metode penilaian dan evaluasi kurikulum.

\section{METODE}

Prosedur penelitian ini mengacu sistem Borg \& Gall (2003) yang pada dasarnya terdiri dari atas dua tujuan, yaitu : 1) mengembangkan produk, dan 2) menguji keefektifan produk dalam mencapai tujuan. Prosedur atau langkah kerja dalam penelitian ini meliputi 1) penelitian pendahuluan, 2) membuat desain, 3) produksi panduan kegiatan dan pembelajaran, 4) uji coba produk. Langkahlangkah prosedur penelitian yang dilakukan tergambar pada bagan dibawah ini. 


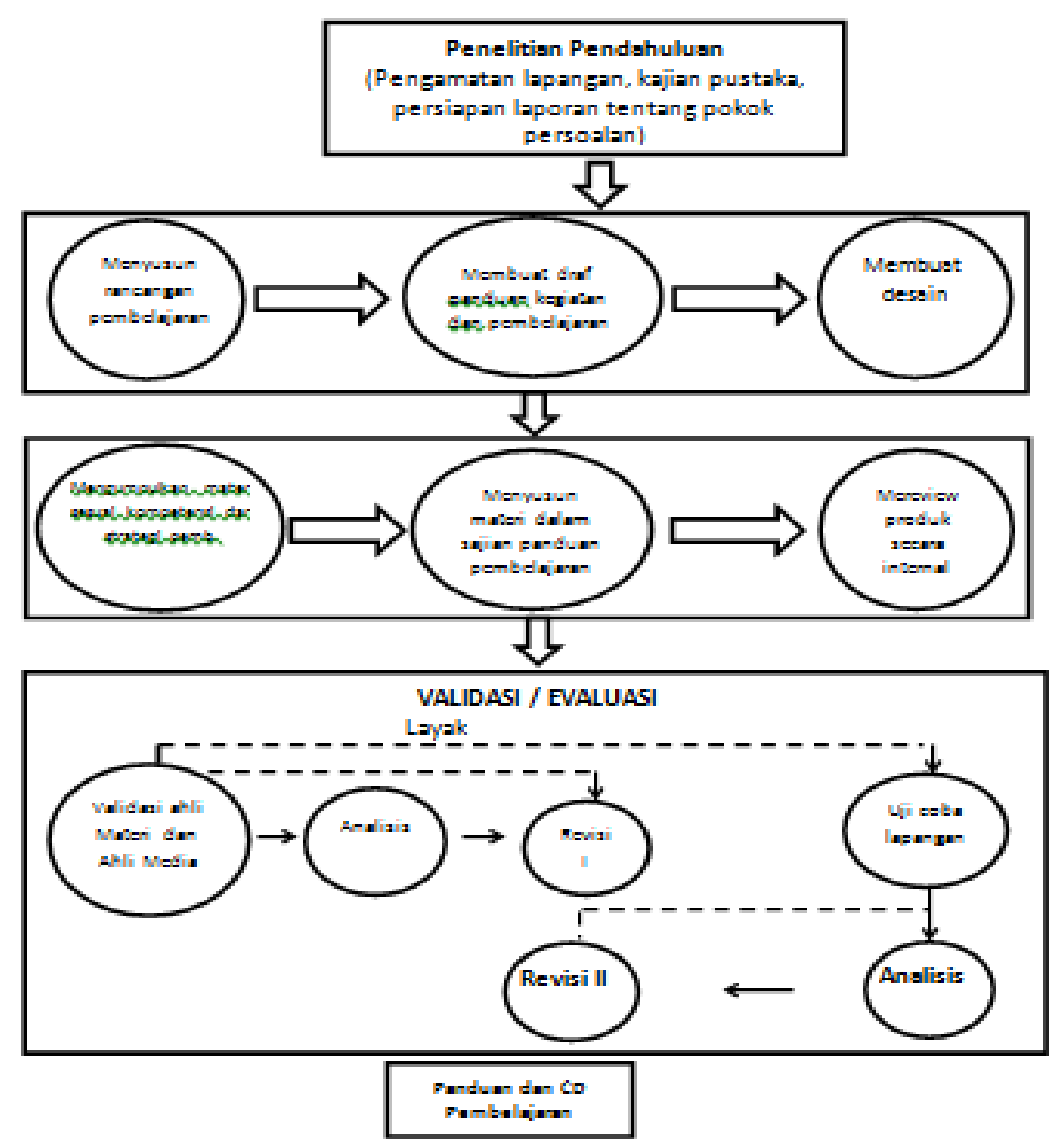

Gambar 1. Prosedur Pengembangan, diadaptasi dan dimodifikasi dari Borg dan Gall

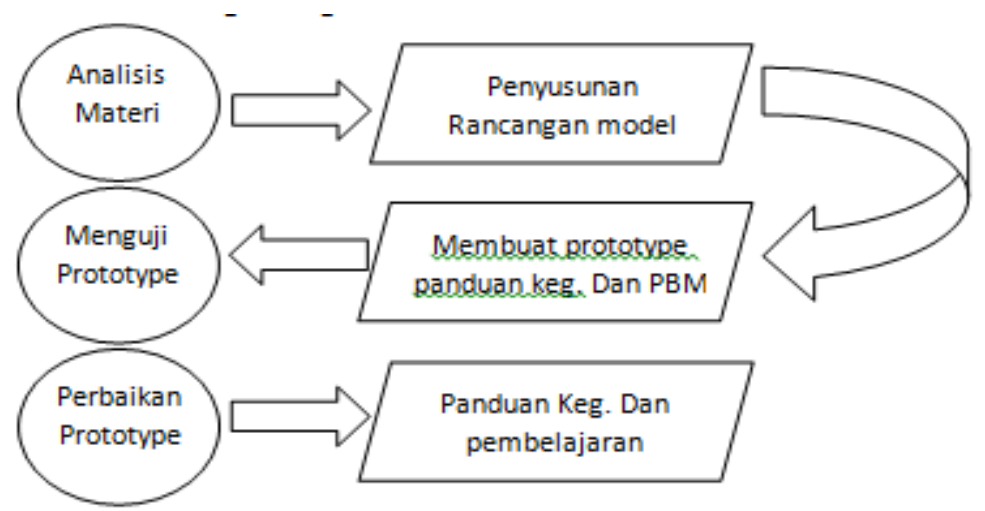

Gambar. 2 Sistematika panduan pembelajaran. 
Sistematika penyajian materi tergambar pada bagan dibawah ini.

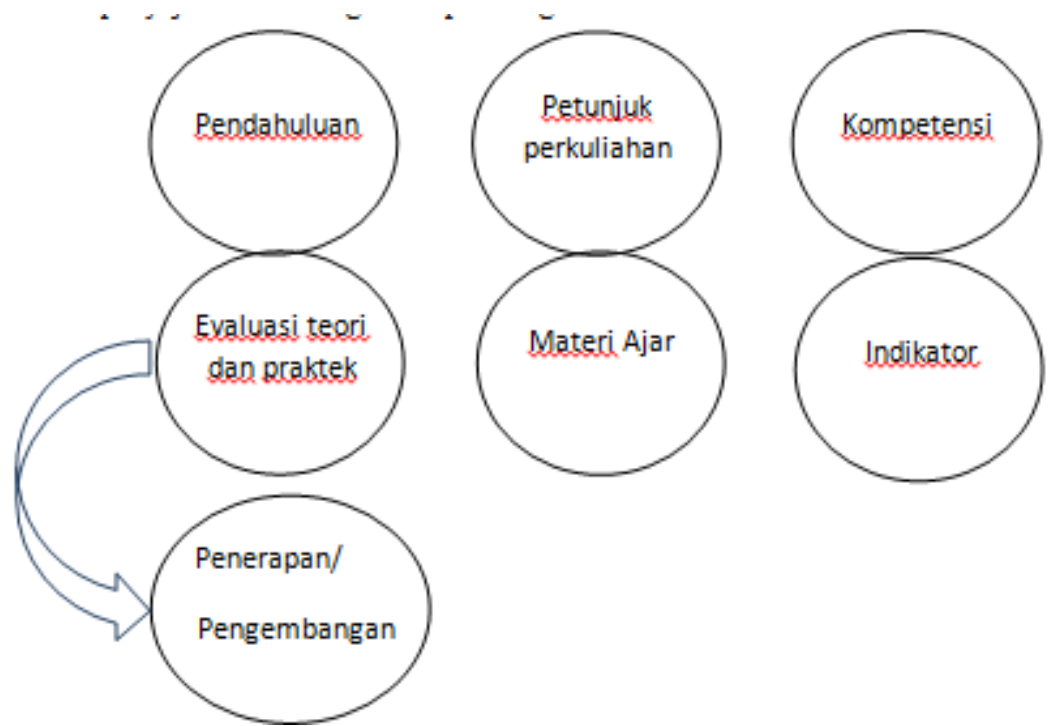

Gambar 3. Sistematika Penyajian Materi

Proses Produksi panduan kegiatan dan pembelajaran tergambar sebagai berikut.

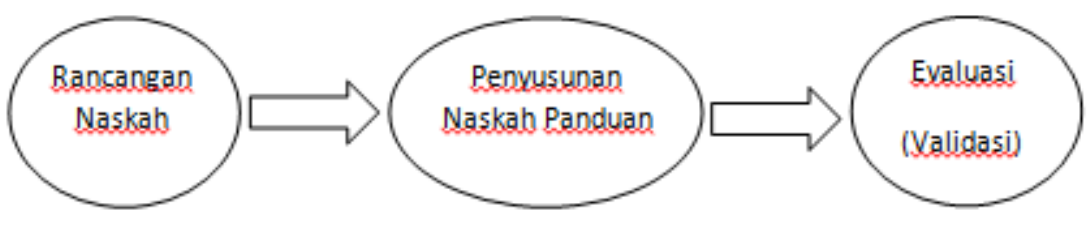

Gambar 4. Proses Produksi panduan kegiatan dan pembelajarran .

Teknik analisa data meliputi analisa data kondisi awal, analisa data kelayakan produk, analisa data keefektifan panduan kegiatan dan pembelajaran dianalisis secara statistik kuantitatif dengan menggunakan persentase keberhasilan dalam mempraktekan panduan kegiatan dan pembelajaran . Panduan kegiatan dan pembelajaran dikatakan efektif jika keberhasilan mahasiswa dalam mempraktekan panduan kegiatan dan pembelajaran serta pengetahuan yang dimil;iki. Untuk melihat keefektifan produk dilakukan melalui pemberian tanggapan/pengetahuan dan praktek pada mahasiswa. Analisa data dilakukan perhitungan prosentase nilai. Setelah nilai prosentase diperoleh maka ditafsirkan dalam kalimat sebagaimana dikemukakan oleh Arikunto, (2006) seperti terlihat pada table

Tabel 1. Kriteria Validasi

\begin{tabular}{ll}
\hline Prosentase & Kriteria Validasi \\
\hline $80-100$ & Valid \\
$60-79$ & Cukup Valid \\
$50-69$ & Kurang Valid \\
$0-49$ & Tidak Valid \\
\hline
\end{tabular}




\section{HASIL DAN PEMBAHASAN}

\section{Hasil}

Hasil desain perangkat pembelajaran geografi desa kota berorientasi riset : meliputi : (1) Menyampaikan tujuan pembelajaran. Tujuan pembelajaran dirumuskan secara operasional dan disampaikan pada pembukaan pembelajaran. Contoh tujuan pembelajarannya adalah mendiskripsikan memilih satu desa melalui literatur on line dengan menelusuri potensi desa serta masalahnya. (2) Melakukan, memulai kegiatan observasi secara on line. (3) Melakukan observasi. Observasi dilakukan untuk mengumpulkan informasi atau data tentang profil desa yang dipilih menjadi objek pembelajaran. (4) Komunikasikan dan konfirmasi. Informasi atau data hasil observasi dikomunikasikan oleh salah satu wakil kelompok, dan dikonfirmasi oleh kelompok yang lain, serta dosen mata kuliah. (5) Mengelaborasi pegetahuan. Untuk memperluas dan mendalami pengetahuan tentang profil desa, potensi desa, masalah desa., para mahasiswa perlu memperluas wawasannya dengan membaca buku, artikel atau melakukan penelusuran secara detail melalui literatur on line serta mendiskusikan dengan dosen mata kuliah geografi desa kota tentang potensi fisik dan non fisik desa yang di pilih sebagai hasil penelusuran secara on line. .(6) Mendiskusikan permasalahan. Berdasarkan data yang telah tekumpul, bahan - bahan yang telah dibaca, para mahasiswa mendiskusikan permasalahan desa Misalnya permasalahan yang disiskusikan adalah "bagaimana potensi desa Cihedeung kabupaten Bandung, bagaimana potensinya serta masalah yang dihadapi desa tersebut.?” Dari diskusi ini diharapkan akan teridentifikasi dengan baik permasalahan penataan pusat dan solusi tindakan yang dapat dilakukan.(7) Melakukan tindakan. Berdasarkan solusi hasil diskusi terhadap permasalahan dapat diambil satu atau beberapa solusi praktis untuk diwujudkan dalam tindakan. (8) Melakukan kesimpulan, refleksi dan tindak lanjut. Setelah ke tujuh langkah pembelajaran dilakukan, langkah terakhir berupa kesimpulan, refleksi dan tindak lanjut. Kesimpulan dilakukan menyatukan antara hasil observasi, elaborasi, permasalahan, dan tindakan. Refleksi dilakukan dengan menanyakan kepada mahasiswa "bagaimana perasaan mereka setelah mengikuti pembelajaran?" dan juga menanyakan rencana tindak lanjut masing-masing mahasiswa.

Hasil validasi produk pengembangan berupa: (1) data hasil validasi ahli pembelajaran, dan (2) data hasil validasiaudien. Data hasil validasi ahli pembelajaran sebagai berikut. 
Dinamika Pembelajaran: Jurnal Ilmiah Pembelajaran

\begin{tabular}{|c|c|c|c|c|c|}
\hline \multirow{2}{*}{ No } & \multirow{2}{*}{ Aspek yang Dinilai } & \multicolumn{2}{|c|}{ Validator I } & \multicolumn{2}{|c|}{ Validator 2} \\
\hline & & Skor & Keterangan & Skor & Keterangan \\
\hline 1 & $\begin{array}{l}\text { Menyampaikan tujuan } \\
\text { pembelajaran }\end{array}$ & 2 & Valid & 2 & Valid \\
\hline 2 & $\begin{array}{l}\text { Melakukan awal } \\
\text { observasi secara on } \\
\text { line }\end{array}$ & 2 & Valid & 2 & Valid \\
\hline 3 & Observasi & 2 & Valid & 2 & Valid \\
\hline 4 & $\begin{array}{l}\text { Komunikasi } \\
\text { Konfirmasi }\end{array}$ & 2 & Valid & 2 & Valid \\
\hline 5 & Elaborasi & 1 & Revisi & 2 & Valid \\
\hline 6 & $\begin{array}{l}\text { Diskusi } \\
\text { Kesimpulan }\end{array}$ & 1 & Revisi & 1 & Revisi \\
\hline
\end{tabular}

Hasil validasi I menunjukkan, bahwa dari 8 (kedelapan) langkah pembelajaran yang divalidasi, terdapat 4 langkah pembelajaran yang memiliki skor 2 atau valid, yaitu langkah penyampaian tujuan pembelajaran, melakukanawal observasi secara on line, observasi, dan komunikasi dan konfirmasi. Sedangkan 4 langkah pembelajaran yang lain memiliki skor 1 atau revisi, yaitu langkah elaborasi, diskusi dan kesimpulan, melakukan tindakan, revisi dan tindak lanjut. Atas dasar usulan validator pertama dilakukan perbaikan produk pengembangan pada langkah-langkah pembelajaran yang perlu revisi tersebut.

Setelah validasi tahap pertama selesai, produk hasil pengembangan yang telah direvisi, diajukan untuk divalidasi tahap kedua. Hasil validasi tahap kedua menunjukka langkah pembelajaran yang telah divalidasi tahap pertama, terdapat 6 (enam) langkah pembelajaran yang memiliki skor 2 atau valid, yaitu menyampaikan tujuan pembelajaran, melakukan safety moment, observasi, komnikasi dan konfirmasi, elaborasi, dan melakukan tindakan. Sedangkan kedua langkah yang lain memiliki skor 1 atau revisi, yaitu diskusi dan kesimpulan, dan refleksi dan tindak lanjut. Atas usulan validator kedua tersebut dilakukan revisi produk pengembangan pada langkah pembelajaran yang perlu revisi. Hasil uji coba produk setelah dilakukan validasi produk pengembangan desain perangkat pembelajaran grografi berbasis riset sebagai berikut. 
Tabel 3. Skor hasil Uji Coba

\begin{tabular}{|c|c|c|c|c|c|}
\hline \multirow{3}{*}{ No } & \multirow{3}{*}{ Item Yang Dinilai } & \multicolumn{2}{|c|}{$\begin{array}{l}\text { Skor dan } \\
\text { Frekuensi }\end{array}$} & \multirow{3}{*}{ Persentase } & \multirow{3}{*}{ Ke terangan } \\
\hline & & & & & \\
\hline & & 1 & 2 & & \\
\hline 1 & $\begin{array}{l}\text { Perumusan tujuan } \\
\text { Pembelajaran }\end{array}$ & 2 & 32 & 94,10 & Valid \\
\hline 2 & $\begin{array}{l}\text { Melakukan observasi } \\
\text { melalui penelusuran } \\
\text { secara on line }\end{array}$ & 3 & 31 & 91,17 & Valid \\
\hline 3 & Observasi & 1 & 33 & 97,00 & Valid \\
\hline 4 & $\begin{array}{l}\text { Komunikasi dan } \\
\text { Konfirmasi }\end{array}$ & 2 & 32 & 94,10 & Valid \\
\hline 5 & Elaborasi & 3 & 31 & 91,17 & Valid \\
\hline 6 & $\begin{array}{l}\text { Diskusi dan } \\
\text { Kesimulan }\end{array}$ & 2 & 32 & 94,10 & Valid \\
\hline 7 & Melakukan Tindakan & 2 & 32 & 94,10 & Valid \\
\hline 8 & $\begin{array}{l}\text { Refleksi dan Tindak } \\
\text { Lanjut }\end{array}$ & 4 & 30 & 88,20 & Valid \\
\hline
\end{tabular}

Dari 8 (kedelapan) langkah pembelajaran, skor tertinggi sebesar 96\%, dan skor terendah $87,80 \%$. Skor tertinggi pada langkah melakukan awal observasi melalui penelusuran secara on linei, dan skor terendah pada langkah penyampaian tujuan pembelajaran, dan refleksi dan tindak lanjut. Skor hasil uji coba tersebut menunjukkan, bahwa secara keseluruhan skor hasil uji coba berada diatas kriteria yang telah ditentukan. Hal itu berarti langkah-langkah pembelajaran dapat diterima oleh mahasiswa dan dapat diterapkan oleh dosen dalam proses perkuliahan. Analisis data hasil validasi I dan validasi II tertera pada tabel berikut. 
Dinamika Pembelajaran: Jurnal Ilmiah Pembelajaran

\begin{tabular}{|c|c|c|c|c|c|c|c|}
\hline \multirow[b]{3}{*}{ No } & \multirow[b]{3}{*}{$\begin{array}{l}\text { Skor } \\
\text { Item }\end{array}$} & \multicolumn{6}{|c|}{ Tabel 4. Tindak Lanjut Hasil Validasi } \\
\hline & & \multicolumn{3}{|c|}{ Validasi I } & \multicolumn{3}{|c|}{ Validasi II } \\
\hline & & $\begin{array}{c}\text { Jumlah } \\
\text { Item }\end{array}$ & $\begin{array}{c}\text { skor } \\
\text { akhir (\%) }\end{array}$ & $\begin{array}{l}\text { Tindak } \\
\text { Lanjut }\end{array}$ & $\begin{array}{c}\text { Jumlah } \\
\text { Item }\end{array}$ & $\begin{array}{c}\text { skor } \\
\text { akhir } \\
(\%)\end{array}$ & $\begin{array}{l}\text { Tindak } \\
\text { Lanjut }\end{array}$ \\
\hline 1 & Skor 1 & 4 & 75 & $\begin{array}{l}\text { Revisi } \\
\text { berat }\end{array}$ & 6 & 87,5 & $\begin{array}{l}\text { Revisi } \\
\text { ringan }\end{array}$ \\
\hline 2 & Skor 2 & & & & 2 & & \\
\hline
\end{tabular}

Masukan validator I, bahwa langkah pembelajaran yang tidak valid tersebut perlu dilakukan revisi. Revisi yang dilakukan, yaitu (1) elaborasi. Dalam kegiatan elaborasi disarankan agar pengetahuan mahasiswa dapat diperluas melalui berbagai sumber, seperti membaca buku teks, media cetak dan elektronik, dan berdiskusi dengan ahli. (2) diskusi dan kesimpulan. Untuk kegiatan diskusi dan kesimpulan disarankan agar langkah ini dapat memastikan setiap mahasiswa berkontribusi pendapat atau gagasan. Untuk kesimpulan disarankan dapat berupa item-item kongkret yang dapat ditindaklanjuti dalam tindakan nyata. (3) melakukan tindakan. Untuk tindakan disarankan agar dapat dibuat perencanaan operasional sebagai acuan di lapangan. (4) refleksi dan tindak lanjut. Untuk refleksi dan tindak lanjut disarankan agar dapat menonjolkan aspek perasaan peserta didik setelah melakukan serangkaian pembelajaran.

Berdasarkan masukan validator II, bahwa langkah pembelajaran yang tidak valid tersebut perlu dilakukan revisi. Revisi yang dilakukan adalah (1) diskusi dan kesimpulan. Kegiatan diskusi dan kesimpulan disarankan agar permasalahan yang didiskusikan merujuk permasalahan nyata yang berdimensi keruangan. (2) refleksi dan tindak lanjut. Untuk refleksi perlu dibuat instrumen yang memudahkan bagi peserta didik mengungkapkan perasaannya, dan data tersebut dapat digunakan bagi pendidik dalam membantu merumuskan tindak lanjut.

Analisis data hasil uji coba menunjukkan skor 252 dari 252 atau 87,74\%. Mengacu pada kriteria kevalidan sebesar $76 \%$, maka skor hasil uji coba lebih besar dari kriteria yang ditetapkan atau 87,74\%>76\%. Berdasarkan kriteria kevalidan tersebut, produk desain pembelajaran geografi desa kota berbasis riset tersebut layak digunakan dan tidak perlu dilalukan uji coba ulang.

Tabel 5. Tindak lanjut masing-masing Item Data

\begin{tabular}{clcccc}
\hline No & Krite ria & \% & $\begin{array}{c}\text { Jumlah } \\
\text { Item }\end{array}$ & \% & $\begin{array}{c}\text { Tindak } \\
\text { lanjut }\end{array}$ \\
\hline 1 & Valid & $>76$ & 8 & 100 & Dipakai \\
2 & Tidak Valid & $<76$ & 0 & 0 & - \\
\hline
\end{tabular}




\section{Pembahasan}

Sumber belajar merupakan salah satu bagian yang penting dalam keberhasilan kegiatan perkuliahan, karena dengan tersedianya sumber belajar yang baik akan mempermudah mahasiswa dalam menyerap informasi tentang materi perkuliahan sehingga mampu memiliki daya alnalisis yang tinggi terhadap masalah yang dikaji. Desa Cihedeung yang berlokasi di kabupaten Bandung sebagai satu desa yang di desain untuk pembelajaran berorientesi riset dan tujuan lainnya untuk sarana pendidikan sebagai sumber belajar. Menurut Ningrum (2009) jenis-jenis sumber belajar terdiri dari benda, karya ilmiah, manusia, dan lingkungan. Desa Cihedeung memiliki potensi sebagai sumber belajar, komponenkomponen yang dapat dijadikan sumber belajar oleh mahasiswa yaitu komponen lingkungan dan manusia. Komponen lingkungan yang dapat dijadikan sebagai sumber belajar adalah profil desa Cihedeung yang sudah termasuk potensi fisik dan non fisik sehingga mahasiswa dapat menganalilisis akibat dari kondisi tersebut seiring dengan lajunya pertumbuhan penduduk.

Hasil penelitian menunjukan bahwa rangkaian komponen sumber belajar yang sudah dihasilkan meliputi langkah sebagai berikut : 1) hasil penyusunan rancangan pembelajaran berbasis riset, 2) hasil pembuatan draft panduan 3) desain pembelajaran, 4) terkumpulnya materi sesuai kompetensi dan strategi pembelajaran, 5)tersusunnya materi dalam dalam sajian panduan, 6) hasil review secara internal. Setelah melewati reciew produk secara internal maka desain pembelajaran yang berbasis reset divalidasi oleh ahli materi kemudian dianalisis dengan melewati revisi i kemudian diuji coba lapangan setelah uji caba lapangan diadakan revisi kedua kalinya kemudian dianalisis 6) hasil akhir dari rancangan pembelajaran ini adalah panduan pembelajaran.

Proses pengembangan meliputi 1) hasil analisis materi geografi desa kota berbasis reset.2) Hasil penyusunan rancangan model pembelajaran geografi desa kota berbasis riset. 3 Hasil penyusunan prototype panduan kegiatan dan proses belajar mengajar. 4) hasil pengujian proto type selanjutnya menghasilkan perbaikan protote dan pada akhirnya tersusunlah perbaikan prototype desain pembelajaran. 5) tersusunnya panduan desain kegiatan dan pembelajara geografi desa berbasis riset.

Sistematika panduan pembelajaran meliputi 1( pendahulua tehnik analisa data meliputi analisa data kondisi awal, analisa data kelayakan produk, analisa data keefektifan panduan kegiatan dan pembelajaran dianalisis secara statistik kuantitatif dengan menggunakan persentase keberhasilan dalam mempraktekan panduan kegiatan dan pembelajaran . Panduan kegiatan dan pembelajaran dikatakan efektif jika keberhasilan mahasiswa dalam mempraktekan panduan kegiatan dan pembelajaran serta pengetahuan yang dimil;iki. Untuk melihat keefektifan produk dilakukan melalui pemberian tanggapan/pengetahuan dan praktek pada mahasiswa. Hasil penelitian menunjukan bahwa sistematika penyajian materi meliputi proses produksi dengan mengikuti alur sebagai berikut hasil rancangan naskah, naskah panduan dan evaluasi (validasi)

Analisa data dilakukan perhitungan prosentase nilai. Setelah nilai prosentase diperoleh maka ditafsirkan dalam kalimat sebagaimana dikemukakan 
oleh Arikunto,2006 seperti terlihat pada tabel berikut ini. Ukuran keberhasilan produk desain pembelajaran mata kuliah geografi desa kota berbasis riset dapat digambarkan melalui tabel berikut ini.

Prosentasi penilaian terhadap penelitian pendahuluan penyusunan desain pembelajaran mata kuliah geografi berbasis reset menunjukan capaiannya sebesar 55\% atau kurang valid sehingga dibutuhkan review dan ahli materi untuk di revisi pertama dan kedua hasil validasi menunjukandiva kelayakannya sehingga dapat diuji coba kembali. Setelah dianalisis hasil validasi sebesar $78 \%$ atau cukup valid.

Hasil penelitian mengenai alur pengembangan dan cakupan materi desain pembelajaran geografi desa kota berbasis reset menunjukan capaiannya sebesar $82 \%$ atau valid. . sementara sistimatika panduan pembelajaran dan dan penyajian materi sebesar $85 \%$ atau valid. Untuk jelasnya hasil penelitian dapat digambarkan melalui tabel berikut ini.

Tabel 6. Persentasi capaian hasil pengembangan desain pembelajaran geografi desa kota di jurusan geografi tahun 2019

\begin{tabular}{llcc}
\hline No & \multicolumn{1}{c}{ Indikator } & \% Capaian & $\begin{array}{c}\text { Kriteria } \\
\text { Validasi }\end{array}$ \\
\hline 1. & Alur penelitian pendahuluan & $45 \%$ & Tidak valid \\
Valid \\
2. & Validasi ahli materi & $82 \%$ & Valid \\
3. $\quad$ - Alur proses pengembangan desain & $85 \%$ & Valid \\
4. Pembelajaran & - Alur pengembangan desain & $87 \%$ & Valid. \\
$\quad$ pembelajaran & $90 \%$ & \\
\hline & Proses produksi panduan kegiatan & & \\
& dan & & \\
\hline
\end{tabular}

Sumber : Hasil penelitian tahun 2019

Berdasarkan tabel diatas maka hasil penelitian pengembangan desain pembelajaran geografi desa kota berbasis riset ini adalah terdiri atas 7 (tujuh) langkah, yaitu tujuan pembelajaran, observai awal, melalui penelusuran objek perkuliahan secara , komunikasi dan konfirmasi, elaborasi dan integrasi, diskusi, menarik kesimpulan, refleksi dan tindak lanjut. Ketujuh langkah pengembangan tersebut telah divalidasi dan diuji coba yang hasilnya menunjukkan, bahwa produk pengembangan tersebut layak digunakan dalam perkuliahan mata kuliah geografi desa kota di jurusan geografi geografi FIS Unima.

Kelayakan desain pembelajaran mata kuliah geografi desa kota yang berbasis reset tersebut dilandasi oleh sejumlah keunggulannya yakni (1) bertitik tolak dari realita yang kontekstual. (2) mengaktifkan berfikir dan bekerja mandiri. (3) mengembangkan berfikir kritis, (4) mengembangkan kebiasaan berbagi pengetahuan/pengalaman. (5) membangun sikap reflektif untuk perbaikan secara terus menerus. (6) membiasakan bekerja dalam tim. 


\section{Dinamika Pembelajaran: Jurnal Ilmiah Pembelajaran}

Keenam keunggulan tersebut muncul, karena desain pembelajaran geografi desa kota berorientasi riset ditopang oleh 4 (empat) pendekatan. Keempat pendekatan tersebut yaitu: pendekatan pembelajaran holistik, pendekatan pembelajaran kontekstual, pendekatan pembelajaran aktif, dan pendekatan pembelajaran kooperatif. Keempat pendekatan tersebut saling berinteraksi menguatkan desain [pembelajaran tersebut.

Pertama, dosen mata kuliah menerapkan prinsip-prinsip pembelajaran holistik (Holistic Learnig). Prinsip pembelajaran holistik adalah knowing the good, feeling the good, dan acting the good. Knowing the good berupa transfer pengetahuan (kognitif) yang baik. Setelahknowing the good harus ditumbuhkanfeeling and loving the good, yakni bagaimana merasakan dan mencintai kebajikan menjadi penggerak yang bisa membuat orang senantiasa mau berbuat sesuatu kebaikan sehingga tumbuh kesadaran mau melakukan perilaku kebajikan, karena kecintaannya pada perilaku kebajikan itu. Setelah terbiasa melakukan kebajikan, maka acting the good yang berupa tindakan-tindakan nyata untuk dibiasakan dalam aktivitas sehari-hari.

Kedua, desain pembelajaran geografi desa kota berbasis riset menerapkan prinsip-prinsip pembelajaran kontekstual(contextual learning). Prinsip pembelajaran kontekstual adalah membantu mahasiswa mengaitkan isi materi perkuliahan dengan keadaan dunia nyata, memotivasi mahasiswa untuk menghubungkan pengetahuan yang diperoleh dan penerapannya dalam kehidupan mahasiswa sebagai anggota keluarga, sebagai warga masyarakat dan sebagai tenaga kerja nantinya (US Depsartment of Education and the National School-toWork Office). Prinsip pembelajaran kontekstual yang diterapkan dalam perkuliahan antara lain (1) melibatkan mahasiswa untuk mengamati/mengopservasi fenomena realitas. (2) memotivasi mahasiswa melakukan tanya jawab dalam kegiatan komunikasi dan konfirmasi. (3) membangun dan memperluas pengetahuan dengan membaca, diskusi, dan presentasi. (4) melibatkan mahasiswa dalam diskusi untuk membangun komunitas belajar. (5) melakukan penilaian otentik.

Ketiga, mahasiswa menerapkan konsep pembelajaran aktif(active learning). Konsep pembelajaran aktif yang digunakan dalam model ini adalah (1) mendorong mahasiswa bekerja untuk menemukan, memproses dan menerapkan informasi. (2) membelajarkan mahasiswa bekerja sama, bekerja secara tim, membagi pekerjaan, dan membangun pandangan umum (Kinney, 2007 dalam Bogart, 2009; Silberman, 2010). Penerapan pembelajaran aktif, antara lain: (1) mendorong mahasiswa melakukan obsevasi untuk mengumpulkan informasi secara on line dan menemukan potensi dan permasalahan desa lainnya menganalisis informasi yang diperolehnya, dan menerapkannya secara individu atau berkelompok. (2) melibatkan mahasiswa untuk bekerja secara tim dalam melakukan telaah terhadap informasi dan menganalisisnya dengan sudut pandang geografis. (3) membangun perspektif baru melalui kegiatan diskusi/pembahasan masalah potensi dan masalah desa yang dipilih sebagai objek pembelajaran.

Keempat, mahasiswa menerapkan prinsip-prinsip pembelajaran kooperatif(cooperative learning). Prinsip-prinsip pembelajaran kooperatif adalah (1) saling ketergantungan positif, (2) taggung jawab perseorangan, (3) tatap muka, 
(4) komunikasi antar anggota, (5) evaluasi proses kelompok (Roger dan Johnson dalam Lie, 2002; Slavin, 2005; Kagan dalam Sutjipto, 2011). Prinsip pembelajaran kooperatif yang diterapkan dalam pengembangan desain pembelajaran, antara lain (1) menciptakan interaksi antar mahasiswa untuk menyelesaikan tugas bersama. (2) menguatkan tanggung jawab perseorangan dalam kegiatan elaborasi pengetahuan. (3) memfasilitasi mahasiswa melakukan tatap muka dalam kelompok dan kelas untuk menelaah pokok perkuliahan. 4) melibatkan mahasiswa mengkomunikasikan hasil penelusuran melalui on line dalam kegiatan komunikasi dan konfirmasi.

Prosentasi penilaian terhadap penelitian pendahuluan penyusunan desain pembelajaran mata kuliah geografi berbasis reset menunjukan capaiannya sebesar 55\% atau kurang valid sehingga dibutuhkan review dan ahli materi untuk di revisi pertama dan kedua hasil validasi menunjukandiva kelayakannya sehingga dapat diuji coba kembali. Setelah dianalisis hasil validasi sebesar $78 \%$ atau cukup valid.

Hasil penelitian pengembangan desain pembelajaran geografi desa kota berorientasi riset ini yakni terdiri dari langkah-langkah sebagai berikut: tujuan pembelajaran, observai awal, melalui penelusuran objek perkuliahan secara komunikasi dan konfirmasi, elaborasi dan integrasi, diskusi, menarik kesimpulan, refleksi dan tindak lanjut. Ketujuh langkah pengembangan tersebut telah divalidasi dan diuji coba yang hasilnya menunjukkan, bahwa produk pengembangan tersebut layak digunakan dalam perkuliahan mata kuliah geografi desa kota di jurusan geografi geografi FIS Unima.

Kelayakan desain pembelajaran mata kuliah geografi desa kota yang berbasis riset tersebut dilandasi oleh sejumlah keunggulan. Keunggulannya , yakni (1) bertitik tolak dari realita yang kontekstual. (2) mengaktifkan berfikir dan bekerja mandiri. (3) mengembangkan berfikir kritis, (4) mengembangkan kebiasaan berbagi pengetahuan/pengalaman. (5) membangun sikap reflektif untuk perbaikan secara terus menerus. (6) membiasakan bekerja dalam tim. Hasil validasi akhir ahli pembelajaran menunjukkan skor perolehan lebih tinggi dari pada kriteria yang ditetapkan, yaitu $87,5 \%>76 \%$. Hasil uji coba tersebut menunjukkan skor perolehan lebih tinggi dari skor kriteria, 87,75\% $>76 \%$. Dengan demikian seluruh langkah pembelajaran dalam penyusuna desai perangkat pembelajaran geografi desa kota berbasis riset memenuhi kriteria kevalidan sehingga dapat digunakan dalam pembelajaran geografi desa kota di jurusan geografi FIS Unima.

\section{KESIMPULAN}

Berdasarkan hasil penelitian diperoleh produk berupa model desain pembelajaran geografi desa kota berbasis riset Desain pembelajaran tersebut terdiri atas 8 (delapan) langkah pembelajaran, yaitu penyampaian tujuan pembelajaran, melakukan observai pendahuluan melalui literatur online. Melakukan obsevasi secara detain dengan berbagai sumber, komunikasi dan 
konfirmasi, elaborasi, diskusi dan kesimpulan, melakukan tindakan, dan refleksi dan tindak lanjut.

Hasil validasi akhir ahli pembelajaran menunjukkan skor perolehan lebih tinggi dari pada kriteria yang ditetapkan, yaitu 87,5\% > 76\%. Hasil uji coba tersebut menunjukkan skor perolehan lebih tinggi dari skor kriteria, 87,75\% > 76\%. Dengan demikian seluruh langkah pembelajaran dalam penyusunan desain perangkat pembelajaran geografi desa kota berbasis riset memenuhi kriteria kevalidan sehingga dapat digunakan dalam pembelajaran geografi desa kota di jurusan geografi FIS Unima. Mahasiswa dalam menerapkan hasil validasi akhir rancangan perkuliahan berbasis riset menghasilkan lebih banyak literatur secara on line.

\section{DAFTAR PUSTAKA}

Abdul Gafur. (2012). Desain Pembelajaran Konsep, Model, Dan Aplikasinya. Jakarta. (Ikapi).

Arikunto, S. (2010). Prosedur Penelitian Suatu Pendekatan Praktik. Jakarta. Rieneka Cipta.

Borg \& Call Bumi Aksara. Sidik, dkk. (2013). Prinsip-prinsip Desain Pembelajaran. Metode Penelinelitian Geografi. Jakarta

Lie, Anita. (2002). Cooperative Learning. Jakarta. Grasindo.

Rosda Karya. Musfah, J. (Algensindo. Rusman. (2013). Model-Model Pembelajaran. Jakarta. PT Raja Grafindo.

Sukma Perdana Prasetya. (2015). Media Pembelajaran Geografi. Yogyakarta: Penerbit Ombak.

Peraturan Menteri Pendidikan Nasional Nomor 22 tahun 2006 tanggal 23 Mei 2006 tentang Standar Isi.

Permendikti, No 44 Tahun 2015 tentang Standar Nasional Pendidikan Tinggi, Jakarta. 